\title{
Profile of tocilizumab and its potential in the treatment of giant cell arteritis
}

\author{
Susan Patricia Mollan ${ }^{1,2}$ \\ John Horsburgh' \\ Bhaskar Dasgupta ${ }^{3}$
}

'Birmingham Neuro-Ophthalmology Unit, University Hospitals Birmingham NHS Foundation Trust, Queen Elizabeth Hospital, Birmingham, ${ }^{2}$ Institute of Metabolism and Systems Research, University of Birmingham, ${ }^{3}$ Department of Rheumatology, Southend University Hospital, Southend-on-Sea, UK
Correspondence: Susan Patricia Mollan Birmingham Neuro-Ophthalmology Unit, University Hospitals Birmingham NHS Foundation Trust, Queen Elizabeth Hospital, Birmingham BI5 2TT, UK

Email susan.mollan@uhb.nhs.uk
This article was published in the following Dove Press journal: Eye and Brain

\begin{abstract}
Giant cell arteritis (GCA) remains a medical emergency due to the threat of permanent sight loss. High-dose glucocorticoids (GCs) are effective in inducing remission in the majority of patients, however, relapses are common which lengthen GC therapy. GC toxicity remains a major morbidity in this group of patients, and conventional steroid-sparing therapies have not yet shown enough of a clinical benefit to change the standard of care. As the understanding of the underlying immunopathophysiology of GCA has increased, positive clinical observations have been made with the use of IL-6 receptor inhibitor therapies, such as tocilizumab (TCZ). This has led to prospective randomized control trials that have highlighted the safety and efficacy of TCZ in both new-onset and relapsing GCA.
\end{abstract}

Keywords: giant cell arteritis, temporal arteritis, Horton disease, interleukin-6, tocilizumab, treatment

\section{Introduction}

Giant cell arteritis (GCA) continues to be a disease of major concern for practicing clinicians $^{1}$ and patients ${ }^{2}$ due to the threat of permanent sight loss and the cumulative toxicity caused by glucocorticoid (GC) therapy. ${ }^{3,4}$ It is the commonest immunomediated primary systemic vasculitis affecting medium-to-large arteries that almost exclusively affects patients over 50 years of age ${ }^{5}$ with an increased incidence with increasing age ${ }^{6}$ and a striking female predominance. ${ }^{7,8}$ The overall prevalence is estimated at $\sim 1$ in $500 .^{8}$

Currently, the main intervention is immediate administration of high-dose GCs. ${ }^{9}{ }^{10}$ There are no randomized controlled trials (RCTs) to support or direct the use of GCs in GCA. Prior to GC therapy, between $30 \%$ and $60 \%$ of patients went blind, ${ }^{11}$ but now the rate of visual loss is somewhere between 5\% and 20\%. ${ }^{12-14}$ Typically, a standard taper of GC is prescribed to all patients according to the clinical symptoms, signs and acute-phase serological markers. ${ }^{9,10}$ Relapses occur, lengthening the treatment, and further complications of the disease occur including aortic aneurysms ${ }^{15,16}$ and late visual loss. ${ }^{17}$ The morbidity associated with high cumulative doses of GC is well established, ${ }^{3,18}$ with $>85 \%$ of patients experiencing at least one side effect. Common GC-induced side effects are diabetes mellitus, osteoporosis and fractures. ${ }^{4}$ GCA, the disease and the side effects of GCs, confers a significant health-related economic burden. ${ }^{19}$

Trials investigating steroid-sparing agents such as azathioprine, ${ }^{20}$ which was shown to be effective at reducing the overall steroid dose, failed due to higher rates of discontinuation when compared to GCs. The evidence for the use of methotrexate (MTX) is 
conflicting $^{21-23}$ and on meta-analysis showed modest benefit. ${ }^{24}$ The RCTs investigating tumor necrosis factor antagonists such as infliximab ${ }^{25}$ and other targeted therapies such as etanercept ${ }^{26}$ and adalimumab, ${ }^{27}$ did not confer a significant enough benefit for a change from standard GC therapy. More recently, a trial investigating the concurrent use of abatacept with corticosteroids showed that at 12 months, $48 \%$ of those receiving abatacept and $31 \%$ of those receiving placebo were in remission $(p=0.049){ }^{28}$

Interleukin (IL)-6 receptor inhibition presents a promising approach, and tocilizumab (TCZ; a recombinant, humanized anti-IL-6 receptor [IL-6R] monoclonal antibody) has undergone RCTs to show efficacy and safety for use in GCA. ${ }^{29,30}$ This review focused on the rationale of IL-6R inhibition, and the trial profile of TCZ in rheumatoid arthritis (RA), thus demonstrating the safety signals and its recent evidence base in the treatment of GCA.

\section{Pathogenesis of GCA}

GCA is a polygenic and multifactorial disease. Genetic association studies have described several genes that are associated with a predisposition to develop GCA. The commonest being genes of the human leukocyte antigen (HLA) class I and II regions. ${ }^{31,32}$ Carriage of $H L A-D R B 1 * 04$ allele is strongly associated with a susceptibility to GCA. ${ }^{33,34}$ There are other genes of interest that are not part of the HLA gene, with the strongest association reported as being protein tyrosine phosphatase, non-receptor type 22 (PTPN22). ${ }^{35}$ Since its early clinical descriptions by Hutchinson ${ }^{36}$ and Horton et $a l,{ }^{37}$ there has long been speculation about the nature of the triggering event in GCA. Some authors have reported a seasonal variation in the disease, ${ }^{38}$ whereas others have not found such an association. ${ }^{39,40}$ Various infectious agents have been linked to the condition; previously, Chlamydia pneumoniae, Mycoplasma pneumoniae and parvovirus B19 have been associated. ${ }^{41,42}$ More recently, the varicella-zoster virus has been reinvestigated, with some groups implicating it as its presence was found in temporal artery biopsy specimens, ${ }^{42}$ whereas others have not corroborated the findings. ${ }^{43,44}$

\section{Immunopathology of GCA}

GCA predominantly affects medium and large arteries of the external cranial branches of the carotid artery and the aorta. Arteries are composed of three layers, namely, the adventitia; the media, which contains smooth muscle cells; and the intima, a network of endothelial cells. Following an unknown trigger, the initial inflammatory cascade starts with a breakdown of the immune privilege in the adventitia, where vascular dendritic cells recruit and activate cluster differentiation $(\mathrm{CD}) 4^{+}$naïve $\mathrm{T}$ cells. $\mathrm{CD} 4^{+} \mathrm{T}$ cells proliferate into T helper (Th) 1 cells, Th17 cells and T regulatory (Treg) cells. Th1 predominantly produces interferon (IFN)- $\gamma$ and IL-2, and Th17 produces IL-17, IL-21, IL-22, IL-8 and IL-26.

Macrophages (Mo) are attracted and differentiate into a heterogeneous group of cells producing a variety of chemokines. Within the adventitia, Mo produce IL-6 and IL-1 $\beta$. In the media, Mo produce metalloproteinases, which destroy the elastic lamina, and growth factors, such as plateletderived growth factor, transforming growth factor (TGF)- $\beta$ and vascular endothelial growth factor, which in turn fuel the intimal hyperplasia. In some, highly activated Mo form multinucleated giant cells. The Mo also produce reactive oxidative species, which cause injury to the smooth muscle of the media. To the injury, arterial cells (vascular smooth muscle cells, endothelial cells and fibroblasts) respond with a dysfunctional repair, which leads to media thinning, luminal occlusion and ischemia. ${ }^{45,46}$

\section{Focus on IL-6}

IL-6 was found to be significantly elevated in the serum of untreated GCA patients, with some patients having persistently high levels after GC treatment. ${ }^{47}$ Furthermore, serum IL-6 levels were found to be a more sensitive marker of disease activity than erythrocyte sedimentation rate $(\mathrm{ESR})^{48}$ and the levels readily suppressed with GC therapy. ${ }^{49}$

IL-6 is a pleiotropic cytokine and was originally described as a B-cell differentiation factor. ${ }^{49}$ It has been found to be produced by T cells, B cells, Mo, endothelial cells and fibroblasts on various stimuli. ${ }^{50}$ IL-6 activates a receptor complex, namely, the IL-6R and the signal-transducing receptor subunit gp130.51 IL-6R occurs as a membrane bound and a soluble form. IL- 6 binds to both of these forms, which can then interact with gp130 and members of the Janus kinase (Jak) family, such as Jak1, Jak2 and tyrosine kinase 2 (Tyk2), which are associated with gp130. ${ }^{52}$

Among its actions, IL-6 stimulates hepatocytes to synthesize and release the acute phase reactants, C-reactive protein (CRP), ${ }^{48}$ and it promotes the transition from acute to chronic inflammation. Of further interest, IL-6 participates in the activation of naïve $\mathrm{T}$ cells and differentiation into Th17 cells in the presence of TGF- $\beta^{53}$ and inhibits TGF- $\beta$-induced Treg cells' differentiation and function. Treg cells function to restrain excessive effector T-cell responses. IL-6 therefore has a critical role in altering the balance between Treg and Th17 cells, and its overproduction contributes to the pathogenesis of GCA and other inflammatory disorders, including RA, 
pancreatitis, multiple sclerosis, systemic lupus erythematosus (SLE), Crohn's disease, asthma, multiple myeloma, colorectal cancer, breast cancer and lymphoma.

Considering the evidence of IL-6 involvement in the immunopathophysiology of GCA makes it a prime therapeutic target. Blocking IL-6 may alter or halt the differentiation of $\mathrm{CD}^{+} 4$ cells into Th-17 cells ${ }^{54,55}$ and potentially could upregulate the generation of Treg cells. ${ }^{56}$

\section{TCZ}

TCZ is a recombinant, humanized anti-IL-6R antibody that competitively inhibits binding of IL- 6 to both the membranebound and soluble IL-6Rs. ${ }^{57}$ It was approved in 2005 to be used in Japan as an orphan drug for Castleman disease. It was subsequently licensed for use to treat adults with moderateto-severe active RA in Europe, Japan, USA and other countries. TCZ has been approved to be prescribed alone or in combination with disease-modifying anti-rheumatic drugs in the pediatric group older than 2 years with the systemic form of juvenile idiopathic arthritis and/or polyarticular juvenile idiopathic arthritis in both the UK and the USA. ${ }^{58,59}$ Additionally, there have been a number of off-license indications reported in the following diseases: Crohn's disease, ${ }^{60} \mathrm{SLE},{ }^{61}$ Takayasu's arteritis, ${ }^{62,63}$ polymyalgia rheumatica $(\mathrm{PMR})^{63,64}$ and adult-onset Still's disease. ${ }^{65}$

\section{Safety profile of TCZ}

Preclinical studies, where systemic plasma steady-state concentrations of TCZ were eight to ten times greater than seen in any clinical trial, showed changes in absolute neutrophil counts likely related to incomplete granulopoiesis or peripheral sequestration and mild-to-moderate elevations of hepatic transaminases. Importantly, there was no measurable effect on electrophysiological performance, blood pressure, cardiac tissue integrity or prothrombotic activity in intravenous (IV) doses up to $50 \mathrm{mg} / \mathrm{kg}$, and there was no detectable change in bone homeostaisis. ${ }^{59}$

The largest human studies highlighting the safety and efficacy of TCZ are in treating autoimmune arthritis, both IV and subcutaneous administrations, which have since been the subject of meta-analysis. In summary, the Cochrane systematic review of eight RCTs $(n=3334)$ demonstrated a significant benefit of TCZ ( $8 \mathrm{mg} / \mathrm{kg}$ IV every 4 weeks) plus MTX over placebo plus MTX in achieving an American College of Rheumatology Rheumatoid Arthritis Score of disease activity of 50 (ARC50) response (38.8\% versus 9.6\%) in RA. ${ }^{66}$ The drug was generally well tolerated across the trials, although a statistically significant association was reported for changes in liver enzymes, total cholesterol and triglycerides. Where treatment was commenced for dyslipidemia, the returning of serum levels to normal was noted in a number of trials. ${ }^{67-69}$

Notable adverse drug reactions included gastrointestinal (GI) disorders such as hemorrhage and perforation (in the AMBITION trial, ${ }^{70}$ one case was fatal). A past history of diverticulitis is a contraindication for using TCZ, particularly if used in conjunction with nonsteroidal anti-inflammatory drugs (NSAIDs), corticosteroids of MTX. The risk of infection is a major consideration, ${ }^{71}$ and this appears to be independent of transient neutropenia ${ }^{72}$ that has been noted in the following trials: TOWARD,${ }^{68}$ OPTION,${ }^{67}$ AMBITION,${ }^{70}$ RADIATE $^{73}$ and LITHE. ${ }^{74}$ Risks of tuberculosis reactivation, malignancy and hepatitis have not been found to be significantly elevated. Patients can also have higher rates of headache and hypertension. ${ }^{68}$ Injection site reactions have been highlighted when using TCZ subcutaneously. ${ }^{75}$ Table 1 highlights the serious adverse events (SAEs) documented in RA trials.

Pharmacokinetic studies in human beings have not shown any differences in changes in gender, age or ethnicity, mild renal impairment or concurrent treatment with NSAIDs, MTX or corticosteroids. ${ }^{59}$ This is an important evidence as the populations studied in RA tend to have a much younger mean age than those who will be treated for GCA (Table 1). As yet, there are no published studies on those with moderateto-severe renal impairment or on those with hepatic impairment or pregnancy.

\section{Experience of TCZ in GCA}

Seitz et $\mathrm{al}^{76}$ described the first case series of IV TCZ in five patients with GCA with concomitant GC use. There was a resulting rapid remission of the condition and normalization of the acute-phase reactants.

Other groups presented their series corroborating these findings. ${ }^{77,78}$

Villiger et $\mathrm{al}^{29}$ published the first RCT of TCZ in GCA. It was a single-center study that enrolled 30 patients with new-onset or relapsing disease. GCA was confirmed by either a positive temporal artery biopsy or large vessel imaging, and all subjects were required to have elevated inflammatory markers (ESR, CRP) at baseline. In all, 20 participants received IV TCZ $8 \mathrm{mg} / \mathrm{kg} /$ month for 52 weeks and 10 participants received placebo. All subjects received concomitant prednisone $1 \mathrm{mg} / \mathrm{kg}$ /day with a steroid taper protocol. Those in remission by 12 weeks received an average of $7 \mathrm{mg}$ /day of prednisone. In all, $85 \%$ of patients in the TCZ group achieved the primary outcome, complete 
Table I Safety of tocilizumab in rheumatoid arthritis studies

\begin{tabular}{|c|c|c|c|c|c|c|c|c|}
\hline Trial name & $\begin{array}{l}\text { Year } \\
\text { published }\end{array}$ & Reference & $\begin{array}{l}\text { Study } \\
\text { length }\end{array}$ & Study design & Study population & $\begin{array}{l}\text { Sample } \\
\text { size }\end{array}$ & $\begin{array}{l}\text { Number } \\
\text { of arms }\end{array}$ & Arms \\
\hline \multirow[t]{7}{*}{ CHARISMA } & 2006 & Maini et a $7^{79}$ & 16 weeks & Multicenter RCT & $\begin{array}{l}\text { Patients with active } \\
\text { RA and an inadequate } \\
\text { response to MTX }\end{array}$ & 359 & 7 & TCZ 2 mg/kg \\
\hline & & & & & & & & TCZ 4 mg/kg \\
\hline & & & & & & & & $\mathrm{TCZ} 8 \mathrm{mg} / \mathrm{kg}$ \\
\hline & & & & & & & & TCZ $2 \mathrm{mg} / \mathrm{kg}+\mathrm{MTX}$ \\
\hline & & & & & & & & $\mathrm{TCZ} 4 \mathrm{mg} / \mathrm{kg}+\mathrm{MTX}$ \\
\hline & & & & & & & & $\mathrm{TCZ} 8 \mathrm{mg} / \mathrm{kg}+\mathrm{MTX}$ \\
\hline & & & & & & & & MTX \\
\hline \multirow[t]{2}{*}{ SAMURAI } & 2005 & $\begin{array}{l}\text { Nishimoto } \\
\text { et al }{ }^{60}\end{array}$ & 52 weeks & $\begin{array}{l}\text { Multicenter, X-ray } \\
\text { reader-blinded RCT }\end{array}$ & $\begin{array}{l}\text { Patients with active RA } \\
\text { of }<5 \text { years duration }\end{array}$ & 306 & 2 & TCZ 8 mg/kg \\
\hline & & & & & & & & DMARD \\
\hline \multirow[t]{3}{*}{ OPTION } & 2008 & Smolen et $\mathrm{al}^{67}$ & 24 weeks & $\begin{array}{l}\text { Double-blind, } \\
\text { randomized, placebo- } \\
\text { controlled, parallel- } \\
\text { group Phase III study }\end{array}$ & $\begin{array}{l}\text { Adult patients } \\
\text { with moderate-to- } \\
\text { severe active RA of } \\
>6 \text { months duration } \\
\text { and an inadequate } \\
\text { response to MTX }\end{array}$ & 623 & 3 & $\mathrm{TCZ} 8 \mathrm{mg} / \mathrm{kg}+\mathrm{MTX}$ \\
\hline & & & & & & & & $\mathrm{TCZ} 4 \mathrm{mg} / \mathrm{kg}+\mathrm{MTX}$ \\
\hline & & & & & & & & Placebo+MTX \\
\hline \multirow[t]{3}{*}{ RADIATE } & 2008 & Emery et $\mathrm{al}^{73}$ & 24 weeks & $\begin{array}{l}\text { Double-blind, } \\
\text { randomized, placebo- } \\
\text { controlled, parallel- } \\
\text { group, Phase III study }\end{array}$ & $\begin{array}{l}\text { Patients with RA } \\
\text { refractory to TNF } \\
\text { antagonist therapy }\end{array}$ & 499 & 3 & $\mathrm{TCZ} 8 \mathrm{mg} / \mathrm{kg}+\mathrm{MTX}$ \\
\hline & & & & & & & & $\mathrm{TCZ} 4 \mathrm{mg} / \mathrm{kg}+\mathrm{MTX}$ \\
\hline & & & & & & & & Placebo+MTX \\
\hline \multirow[t]{2}{*}{ SATORI } & 2008 & $\begin{array}{l}\text { Nishimoto } \\
\text { et al }{ }^{62}\end{array}$ & 24 weeks & $\begin{array}{l}\text { Double-blind, } \\
\text { randomized, } \\
\text { controlled, } \\
\text { multicenter study }\end{array}$ & $\begin{array}{l}\text { Active RA patients } \\
\text { with inadequate } \\
\text { response to MTX }\end{array}$ & 125 & 2 & $\begin{array}{l}\text { TCZ } 8 \text { mg/ } \\
\text { kg+placebo }\end{array}$ \\
\hline & & & & & & & & Placebo+MTX \\
\hline \multirow[t]{2}{*}{ AMBITION } & 2010 & Jones et $\mathrm{a}^{70}$ & 24 weeks & $\begin{array}{l}\text { Double-blind, double- } \\
\text { dummy, parallel-group, } \\
\text { randomized study }\end{array}$ & $\begin{array}{l}\text { Adult patients with } \\
\text { moderate-to-severe } \\
\text { RA for }>3 \text { months }\end{array}$ & 673 & $2 *$ & MTX \\
\hline & & & & & & & & $\mathrm{TCZ} 8 \mathrm{mg} / \mathrm{kg}$ \\
\hline \multirow[t]{3}{*}{ LITHE } & 2011 & $\begin{array}{l}\text { Kremer } \\
\text { et al }{ }^{69}\end{array}$ & 104 weeks & $\begin{array}{l}\text { Randomized, placebo- } \\
\text { controlled, parallel- } \\
\text { group, multicenter } \\
\text { Phase III trial }\end{array}$ & $\begin{array}{l}\text { Patients with } \\
\text { moderate-to-severe } \\
\text { RA and an inadequate } \\
\text { response to MTX }\end{array}$ & 1196 & 3 & $\mathrm{TCZ} 4 \mathrm{mg} / \mathrm{kg}+\mathrm{MTX}$ \\
\hline & & & & & & & & $\mathrm{TCZ} 8 \mathrm{mg} / \mathrm{kg}+\mathrm{MTX}$ \\
\hline & & & & & & & & Placebo+MTX \\
\hline
\end{tabular}




\begin{tabular}{|c|c|c|c|c|c|c|c|c|c|c|}
\hline $\begin{array}{l}\text { Subgroup } \\
\text { sample }\end{array}$ & $\begin{array}{l}\text { Mean } \\
\text { age, } \\
\text { years }\end{array}$ & $\begin{array}{l}\text { Female, } \\
\%\end{array}$ & $\begin{array}{l}\text { Baseline } \\
\text { DAS28 }\end{array}$ & $\begin{array}{l}\text { Primary end } \\
\text { point }\end{array}$ & $\begin{array}{l}\text { ACR20 } \\
(\%)\end{array}$ & $\begin{array}{l}\text { ACR50 } \\
(\%)\end{array}$ & $\begin{array}{l}\text { ACR70 } \\
(\%)\end{array}$ & $\begin{array}{l}\text { DAS28 } \\
<2.6(\%)\end{array}$ & $\begin{array}{l}\text { Number } \\
\text { of } \\
\text { patients } \\
\text { with SAE }\end{array}$ & $\begin{array}{l}\text { Most } \\
\text { common } \\
\text { SAEs with } \\
\text { TCZ }\end{array}$ \\
\hline 53 & 52.2 & 83 & 6.48 & $\begin{array}{l}\text { ACR20@ } \\
\text { I6 weeks }\end{array}$ & 64 & 32 & 2 & & 8 & \\
\hline 54 & 49.3 & 76 & 6.55 & & 63 & 37 & 6 & & 5 & \\
\hline 52 & 50.1 & 73 & 6.43 & & 74 & 53 & 16 & 34 & 3 & \\
\hline 52 & 49.2 & 87 & 6.58 & & 31 & 6 & 14 & & 4 & \\
\hline 49 & 50.2 & 76 & 6.34 & & 61 & 28 & 12 & & 1 & \\
\hline 50 & 50.1 & 78 & 6.47 & & 63 & 41 & 37 & 17 & 7 & \\
\hline 49 & 50.9 & 93 & 6.75 & & 41 & 29 & 16 & 8 & 2 & $\begin{array}{l}\text { Infections and GI } \\
\text { disorders }\end{array}$ \\
\hline 157 & 52.9 & 79.60 & 6.5 & $\begin{array}{l}\text { Radiographic } \\
\text { progression }\end{array}$ & & $\begin{array}{l}\text { Mean sha } \\
2.3\end{array}$ & p score: & & 12 & \\
\hline 145 & 53.1 & 82.10 & 6.4 & & & $\begin{array}{l}\text { Mean sha } \\
6.1\end{array}$ & p score: & & 8 & \\
\hline 205 & 50.8 & 85 & 6.8 & $\begin{array}{l}\text { ACR20@ } \\
24 \text { weeks }\end{array}$ & 59.0 & 44 & 22 & 27 & 6 & \\
\hline 213 & 51.4 & 82 & 6.8 & & 48.0 & 31 & 12 & 13 & 3 & \\
\hline 204 & 50.6 & 78 & 6.8 & & 26.0 & 11 & 2 & 0.8 & 2 & Infections \\
\hline 170 & 53.9 & 84 & 6.79 & $\begin{array}{l}\text { ACR20 @ } \\
24 \text { weeks }\end{array}$ & 50.0 & 28.8 & 12.4 & 30.10 & 11 & \\
\hline 161 & 50.9 & 81 & 6.78 & & 30.4 & 16.8 & 5.0 & 7.60 & 12 & \\
\hline 158 & 53.4 & 79 & 6.8 & & 10.1 & 3.8 & 1.3 & 1.60 & 18 & $\begin{array}{l}\text { Infections, GI } \\
\text { symptoms, rash and } \\
\text { headache }\end{array}$ \\
\hline 61 & 52.6 & 90.10 & 6.1 & $\begin{array}{l}\text { ACR20@ } \\
24 \text { weeks }\end{array}$ & 80.3 & 49.2 & 29.5 & 43 & 4 & \\
\hline 64 & 50.8 & 75 & 6.2 & & 25.0 & 10.9 & 6.3 & 1.60 & 3.00 & $\begin{array}{l}\text { Most commonly } \\
\text { nasopharyngitis }\end{array}$ \\
\hline 284 & 50 & 79 & 6.8 & $\begin{array}{l}\text { ACR20@ } \\
24 \text { weeks }\end{array}$ & 69.9 & 44.1 & 28 & 33.6 & 11 & \\
\hline 286 & 50.7 & 83 & 6.8 & & 52.5 & 33.5 & 15.1 & 12.1 & 8 & $\begin{array}{l}\text { Infections and GI } \\
\text { disorders }\end{array}$ \\
\hline 399 & 51.4 & 84 & 6.5 & $\begin{array}{l}\text { Genant-modified } \\
\text { total sharp score }\end{array}$ & & & & & & \\
\hline 398 & 53.4 & 82 & 6.6 & $\begin{array}{l}\text { AUC for change } \\
\text { in HAQ-DI }\end{array}$ & 54.5 & 38.9 & 22.4 & 64.7 & & \\
\hline 392 & 51.3 & 83 & 6.5 & & 29.3 & 19.8 & 12.2 & 52.9 & & $\begin{array}{l}\text { Infections, } \\
\text { hypertension } \\
\text { and increased } \\
\text { transaminase levels }\end{array}$ \\
\hline
\end{tabular}

(Continued) 
Table I (Continued)

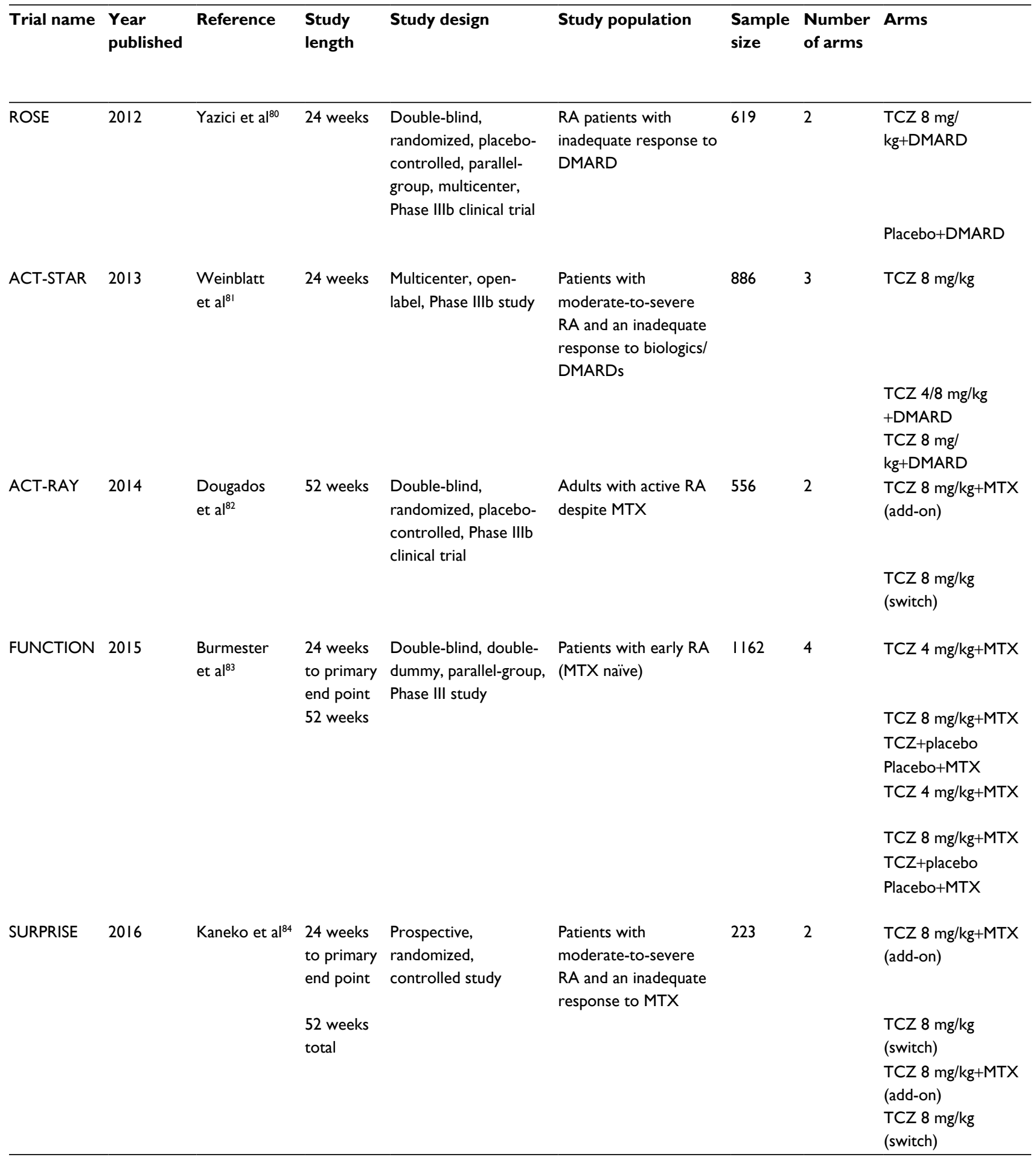

Abbreviations: ACR, American College of Rheumatology Rheumatoid Arthritis Score of disease activity; AUC, area under the curve; DAS, Disease Activity Score; DMARD, disease-modifying anti-rheumatic drug; GI, gastrointestinal; HAQ-DI, Health Assessment Questionnaire Disability Index; MTX, methotrexate; RA, rheumatoid arthritis; RCT, randomized controlled trial; SAE, serious adverse event; TCZ, tocilizumab; TNF, tumor necrosis factor.

remission by week 12 , versus only $40 \%$ of patients in the control group, $p=0.03$. In addition, relapse-free survival at 52 weeks was observed in both groups $(85 \% \mathrm{TCZ}$ versus $20 \%$ placebo, $p=0.001){ }^{29}$
The cumulative $\mathrm{GC}$ dose at 52 weeks $(43 \mathrm{mg} / \mathrm{kg}$ versus $110 \mathrm{mg} / \mathrm{kg}, p=0.0005$ ) was significantly better in the TCZ treatment group. SAEs occurred with equal frequencies between groups. On detailed examination, seven subjects 


\begin{tabular}{|c|c|c|c|c|c|c|c|c|c|c|}
\hline $\begin{array}{l}\text { Subgroup } \\
\text { sample }\end{array}$ & $\begin{array}{l}\text { Mean } \\
\text { age, } \\
\text { years }\end{array}$ & $\begin{array}{l}\text { Female, } \\
\%\end{array}$ & $\begin{array}{l}\text { Baseline } \\
\text { DAS28 }\end{array}$ & $\begin{array}{l}\text { Primary end } \\
\text { point }\end{array}$ & $\begin{array}{l}\text { ACR20 } \\
(\%)\end{array}$ & $\begin{array}{l}\text { ACR50 } \\
(\%)\end{array}$ & $\begin{array}{l}\text { ACR70 } \\
\text { (\%) }\end{array}$ & $\begin{array}{l}\text { DAS28 } \\
<2.6(\%)\end{array}$ & $\begin{array}{l}\text { Number } \\
\text { of } \\
\text { patients } \\
\text { with SAE }\end{array}$ & $\begin{array}{l}\text { Most } \\
\text { common } \\
\text { SAEs with } \\
\text { TCZ }\end{array}$ \\
\hline 409 & 55.2 & 79.5 & 8.62 & $\begin{array}{l}\text { ACR50 @ } \\
24 \text { weeks }\end{array}$ & & 30.1 & & & & \\
\hline 205 & 55.8 & 83.9 & 8.52 & & & 11.2 & $\begin{array}{l}\text { See } \\
\text { study }\end{array}$ & See study & & \\
\hline 138 & 53.5 & 79.7 & 6.01 & $\begin{array}{l}\text { Safety and } \\
\text { tolerability of } \\
\text { TCZ }\end{array}$ & 46 & 21.2 & 5.8 & 19.80 & 8 & \\
\hline 364 & 55.6 & 75 & 5.66 & & 42.3 & 21.4 & 6.5 & 20.60 & 29 & \\
\hline 381 & 54 & 77.7 & 5.54 & & 48.7 & 22.8 & 8.2 & 25.20 & 32 & Infections \\
\hline 277 & 53 & 81.9 & 6.33 & DAS28 remission & 70.8 & 55.4 & 31.4 & 45.5 & 22 & \\
\hline 276 & 53.6 & 78.6 & 6.36 & & 69.2 & 50.2 & 31.2 & 36.6 & 27 & \\
\hline 288 & 51.2 & 79 & 6.7 & $\begin{array}{l}\text { DAS28 remission } \\
\text { @ } 24 \text { weeks }\end{array}$ & & & & 31.90 & 29 & \\
\hline 290 & 49.5 & 79 & 6.7 & & & & & 44.80 & 31 & \\
\hline 292 & 49.9 & 75 & 6.7 & & & & & 38.70 & 25 & \\
\hline 287 & 49.6 & 80 & 6.6 & & & & & $15 \%$ & 24 & \\
\hline & & & & $\begin{array}{l}\text { DAS28 remission } \\
\text { @ } 52 \text { weeks }\end{array}$ & & & & 34 & & \\
\hline & & & & & & & & $\begin{array}{l}49 \\
39.40\end{array}$ & & \\
\hline & & & & & & & & 19.50 & & $\begin{array}{l}\text { Most commonly } \\
\text { infections }\end{array}$ \\
\hline 115 & 55.8 & 87 & 5.1 & $\begin{array}{l}\text { DAS28 remission } \\
\text { @ } 24 \text { weeks }\end{array}$ & 74.8 & 54.8 & 33 & 69.6 & 16 & \\
\hline \multirow[t]{3}{*}{111} & 56.3 & 86.5 & 5.3 & & 69.4 & 54.1 & 34.3 & 55 & 9 & \\
\hline & & & & $\begin{array}{l}\text { DAS28 remission } \\
\text { @ } 52 \text { weeks }\end{array}$ & 73.9 & 62.6 & 47 & 72.2 & & \\
\hline & & & & & 77.5 & 63.1 & 44.1 & 70.3 & & $\begin{array}{l}\text { Infections and } \mathrm{Gl} \\
\text { disorders }\end{array}$ \\
\hline
\end{tabular}

in the TCZ arm experienced SAEs, as documented by the investigators. These included three GI complications, one severe infection, one Stevens-Johnson syndrome, one tinnitus and one GC-induced psychosis. ${ }^{29}$

The largest RCT in GCA to date is the GiACTA trial. ${ }^{30}$ This is a multicenter RCT where 251 GCA patients were enrolled to assess the efficacy and safety ofTCZ in GCA. It is also the first RCT to compare different doses and durations of GC therapy in a masked trial. At baseline, patients with active GCA (new or relapsing) with either a positive temporal artery biopsy or proof of large vessel disease and with associated elevation in acute-phase reactants were eligible for enrollment (Box 1). ${ }^{85}$ 
Box I Enrollment criteria adapted from baseline characteristics of GiACTA

\section{GiACTA eligibility criteria:}

$\checkmark \geq 50$ years of age

$\checkmark$ History of ESR $\geq 50 \mathrm{~mm} / \mathrm{h}$ or CRP $\geq 2.45 \mathrm{mg} / \mathrm{dL}$ if ESR was unavailable

Active disease: signs and symptoms of GCA and ESR $\geq 30 \mathrm{~mm} / \mathrm{h}$ or CRP $\geq 1 \mathrm{mg} / \mathrm{dL}$ within 6 weeks of baseline

At least one of the following:

$\checkmark$ Unequivocal cranial symptoms of GCA (new-onset localized headache, scalp or temporal artery tenderness, ischemia-related vision loss or otherwise unexplained mouth or jaw pain on mastication)

$\checkmark$ Unequivocal symptoms of PMR (shoulder and/or hip girdle pain associated with inflammatory stiffness)

And at least one of the following:

$\checkmark$ TAB revealing features of GCA

$\checkmark$ Evidence of large-vessel vasculitis (angiography or imaging study such as MRA, CTA or PET-CT)

Abbreviations: CRP, C-reactive protein; CTA, computerized tomography angiography; ESR, erythrocyte sedimentation rate; GCA, giant cell arteritis; MRA, magnetic resonance angiography; PET-CT, positron emission tomography - computerized tomography; PMR, polymyalgia rheumatica; TAB, temporal artery biopsy.

Patients were allowed to be on stable doses of MTX with a reduction or discontinuation allowed within the study protocol. Initiation of MTX or increase in dose was not permitted. Prior use of IV methylprednisolone was not allowed. At baseline, open-label prednisone between 20 and $60 \mathrm{mg} /$ day was allowed at the investigator discretion and according to the disease activity. The dose of prednisone at $<20 \mathrm{mg} /$ day during the GC taper was masked to the investigators and subjects. As TCZ has a profound effect on the acute-phase reactants and other liver enzymes, the study required there to be two investigators/assessors: one masked to all the biochemical results and the other to assess the results. ${ }^{85}$

They were randomized to one of four treatment arms. The arms were:

1. $\mathrm{PBO}+26$, the short-course 26 -week prednisone taper and placebo (50 patients);

2. $\mathrm{PBO}+52$, the long-course 52-week prednisone taper and placebo (51 patients);

3. TCZ QW, weekly subcutaneous TCZ $162 \mathrm{mg}$ and 26-week course of prednisone (100 patients); and

4. TCZ $\mathrm{Q}_{2} \mathrm{~W}$, every other week subcutaneous TCZ $162 \mathrm{mg}+26$-week course of prednisone (49 patients).

There were several key definitions set for the GiACTA trial Table 2). ${ }^{30}$

Escape prednisone was allowed; however, if the cumulative dose was $>100 \mathrm{mg}$, the subject would be classed as not in remission or a nonresponder. The primary end points included sustained remission, with testing of superior TCZ QW compared to $\mathrm{PBO}+26$ and non-inferior TCZ QW compared to PBO-52. The secondary end points were the time to first flare, the cumulative prednisone dose and quality of life measures.

The results of the GiACTA showed that the proportion of patients achieving sustained remission at 52 weeks while adhering to the prednisone taper was achieved significantly more frequently in both TCZ arms (56\% of weekly TCZ group and $53 \%$ of the every-other-week TCZ group) as compared with the 26-week prednisone placebo group $(14 \%, p<0.0001)$ and with the 52 -week prednisone placebo group $\left(17 \%, p<0.0001 \mathrm{TCZ} \mathrm{QW}\right.$ and $\left.p=0.002 \mathrm{TCZ} \mathrm{Q}_{2} \mathrm{~W}\right){ }^{30}$ The GiACTA also provided a unique insight into the natural history of GCA as at 12 months, and $14 \%$ of the 26 -week placebo arm stayed in remission. ${ }^{30}$ This is early evidence that in a small portion of patients, less treatment is required to induce remission; more research in this area would be helpful. Biomarkers of disease activity and clinical activity rating scores are sought in GCA to help to guide treatment decisions in the future. ${ }^{30}$

The time to first flare showed a clear differentiation between TCZ arms and prednisone-only groups with the time to first flare being significantly longer for TCZ groups. TCZ showed a significant steroid sparing effect with patients in both TCZ-treatment groups being exposed to significantly less prednisone over time, which included escape prednisone. The median cumulative dose of prednisone was $1862 \mathrm{mg}$ in each TCZ group versus $3817.5 \mathrm{mg}$ in 52-week placebo arm. With a fair spread of new-onset and relapsing GCA patients between all four treatment arms, further analysis reported that the results held significant for both types of patients who entered the trial. ${ }^{30}$ Of note, there were more relapses occurring during tapering doses between 5 and $0 \mathrm{mg}$, particularly in the 2-week TCZ and 26-week placebo arms of the trial. It may be for some that there is a requirement for a long-term maintenance dose of prednisone between 2.5 and $5 \mathrm{mg}$ daily.

The percentage of adverse events (AEs) across all four trial arms was similar, with infections being the commonest AEs. There were a higher number of SAEs in the prednisone and placebo arms of the trial compared to those of the TCZ arms. Overall withdrawals were higher in the TCZ arms at TCZ QW (6\%) and TCZ $\mathrm{Q}_{2} \mathrm{~W}(4 \%)$ compared to $\mathrm{PBO}+26$ $(4 \%)$ and $\mathrm{PBO}+52(2 \%){ }^{30}$ 
Table 2 GiACTA trial definitions adapted from Stone et a ${ }^{30}$

\begin{tabular}{ll}
\hline Trial parameter & Trial definition \\
\hline Flare & $\begin{array}{l}\text { The recurrence of signs or symptoms of GCA and/or ESR }(\geq 30 \text { mm/h) which was attributable to GCA as determined } \\
\text { by the investigator and necessitating an increase in the prednisone dose } \\
\text { The absence of flare and normalization of CRP }(<\mathrm{I} \mathrm{mg} / \mathrm{dL}) \text {. A single CRP elevation }(\geq \mathrm{I} \mathrm{mg} / \mathrm{dL}) \text { was not considered an } \\
\text { absence of remission unless CRP remained elevated }(\geq \mathrm{I} \mathrm{mg/dL)} \mathrm{at} \mathrm{the} \mathrm{next} \mathrm{study} \mathrm{visit.} \mathrm{Remission} \mathrm{should} \mathrm{also} \mathrm{occur} \\
\text { within } 12 \text { weeks of randomization }\end{array}$ \\
Sustained remission & The absence of flare following induction of remission that was maintained up to the 52-week time point
\end{tabular}

Abbreviations: GCA, giant cell arteritis; ESR, erythrocyte sedimentation rate; CRP, C-reactive protein.

The GiACTA study is the largest to date in the field of GCA and will likely encourage a review of the accepted ACR 1990 criteria for the diagnosis of GCA. More than one-third of patients were enrolled based on findings of large-vessel imaging studies (magnetic resonance angiography, computerized tomography angiography or positron emission tomography - computerized tomography) alone; $37 \%$ of patients had positive imaging studies with either no temporal artery biopsy (TAB) or negative TAB. Only $10 \%$ of patients had both positive TAB and positive imaging study findings. ${ }^{85}$

Presently, there are a few limitations to the therapeutic use of monoclonal antibodies in GCA. The on-the-face high cost of the therapy compared to conventional GC treatment is likely to cause funding bodies to question switching therapies. However, this will be mitigated by the cost of ongoing risk of relapse and the significant burden of short-term increased infection rate in $\mathrm{GCA}^{86}$ and long-term side effects from GC toxicity. ${ }^{3}$ Treatment with TCZ is currently IV or subcutaneous, which is an invasive route of administration. Like GCs, TCZ has the potential for SAEs, as evidenced in the RCTs of RA. ${ }^{6}{ }^{\mathrm{IL}}-6$ inhibition is one targeted treatment in a disease with multiple immunological facets, and one case, treated with TCZ, reported persistent vasculitis of medium-sized and large vessels on autopsy. ${ }^{63}$ There are other biologic agents that are being trialed in GCA, in addition to anti-IL-6-directed therapies, and emerging reports describing the use of biologics that inhibit T cells; cytokines IL-1, IL-12 and IL-23; and $\mathrm{B}$ cells in patients with relapsing disease.

There are a number of factors that remain unanswered, such as the role of TCZ in immediate emergency treatment in sight-threatening disease, and yet to be determined is how to maintain long-term sustained remission. ${ }^{87}$ The evidence for using TCZ to initiate remission of GCA is strong, ${ }^{29,30}$ and follow-up studies will help guide the field's next steps.

\section{Disclosure}

SPM has received honoraria for service on advisory boards for Roche and represented the Royal College of Ophthalmologists at the National Institute for Health and Clinical Excellence. JH has no disclosures to report. BD has received honoraria for lectures and served on advisory boards for the National Institute for Health and Clinical Excellence, Roche, Munidpharma, Napp, Merck, and GSK, and has received grant support from the European League Against Rheumatism, American College of Rheumatology, Health Technology Assessment UK, and Research for Patient Benefit UK. The authors report no other conflicts of interest in this work.

\section{References}

1. Gonzalez-Gay MA, Castaneda S, Llorca J. Giant cell arteritis: visual loss is our major concern. J Rheumatol. 2016;43(8):1458-1461.

2. Hellmann DB, Uhlfelder ML, Stone JH, et al. Domains of health-related quality of life important to patients with giant cell arteritis. Arthritis Care Res. 2003;49(6):819-825.

3. Proven A, Gabriel SE, Orces C, O'Fallon WM, Hunder GG. Glucocorticoid therapy in giant cell arteritis: duration and adverse outcomes. Arthritis Rheum. 2003;49(5):703-708.

4. Wilson JC, Sarsour K, Collinson N, et al. Serious adverse effects associated with glucocorticoid therapy in patients with giant cell arteritis (GCA): a nested case-control analysis. Semin Arthritis Rheum. 2017;46(6):819-827.

5. Lawrence RC, Helmick CG, Arnett FC, et al. Estimates of the prevalence of arthritis and selected musculoskeletal disorders in the United States. Arthritis Rheum. 1998;41(5):778-799.

6. Machado EB, Michet CJ, Ballard DJ, et al. Trends in incidence and clinical presentation of temporal arteritis in Olmsted County, Minnesota, 1950-1985. Arthritis Rheum. 1988;31(6):745-749.

7. Wilson JC, Sarsour K, Collinson N, et al. Incidence of outcomes potentially associated with corticosteroid therapy in patients with giant cell arteritis. Semin Arthritis Rheum. 2017;46(5):650-656.

8. Crowson CS, Matteson EL. Contemporary prevalence estimates for giant cell arteritis and polymyalgia rheumatica. Semin Arthritis Rheum. 2017;47(2):253-256.

9. Dasgupta B, Borg FA, Hassan N, et al. BSR and BHPR guidelines for the management of giant cell arteritis. Rheumatology (Oxford). 2010;49(8):1594-1597.

10. Mukhtyar C, Guillevin L, Cid MC, et al. EULAR recommendations for the management of large vessel vasculitis. Ann Rheum Dis. 2009;68(3):318-323.

11. Birkhead NC, Wagener HP, Shirck RM. Treatment of temporal arteritis with adrenal corticosteroids; results in fifty-five cases in which lesion was proved at biopsy. J Am Med Assoc. 1957;163(10):821-827.

12. Chen JJ, Leavitt JA, Fang C, Crowson CS, Matteson EL, Warrington KJ. Evaluating the incidence of arteritic ischemic optic neuropathy and other causes of vision loss from giant cell arteritis. Ophthalmology. 2017;123(9):1999-2003.

13. Saleh M, Turesson C, Englund M, Merkel PA, Mohammad AJ. Visual complications in patients with biopsy-proven giant cell arteritis: a population-based study. J Rheumatol. 2016;43(8):1559-1565.

14. Salvarani C, Cimino L, Macchioni P, et al. Risk factors for visual loss in an Italian population-based cohort of patients with giant cell arteritis. Arthritis Rheum. 2005;53(2):293-297. 
15. Kermani TA, Warrington KJ, Crowson CS, et al. Large-vessel involvement in giant cell arteritis: a population-based cohort study of the incidence-trends and prognosis. Ann Rheum Dis. 2013;72(12):1989-1994.

16. Mackie SL, Hensor EMA, Morgan AW, Pease CT. Should I send my patient with previous giant cell arteritis for imaging of the thoracic aorta? A systematic literature review and meta-analysis. Ann Rheum Dis. 2013;73(1):143-148.

17. Chan CCK, Paine M, O'day J. Predictors of recurrent ischemic optic neuropathy in giant cell arteritis. JNeuroophthalmol. 2005;25(1):14-17.

18. Petri H, Nevitt A, Sarsour K, Napalkov P, Collinson N. Incidence of giant cell arteritis and characteristics of patients: Data-driven analysis of comorbidities. Arthritis Care Res. 2015;67(3):390-395.

19. Koster MJ, Achenbach SJ, Crowson CS, Maradit-Kremers H, Matteson EL, Warrington KJ. Healthcare use and direct cost of giant cell arteritis: a population-based study. J Rheumatol. 2017;56(11):1939-1944.

20. De Silva M, Hazleman BL. Azathioprine in giant cell arteritis/ polymyalgia rheumatica: a double-blind study. Ann Rheum Dis. 1986;45(2):136-138.

21. Hoffman GS, Cid MC, Hellmann DB, et al. A multicenter, randomized, double-blind, placebo-controlled trial of adjuvant methotrexate treatment for giant cell arteritis. Arthritis Rheum. 2002;46(5):1309-1318.

22. Spiera RF, Mitnick HJ, Kupersmith M, et al. A prospective, double-blind, randomized, placebo controlled trial of methotrexate in the treatment of giant cell arteritis. Clin Exp Rheumatol. 2001;19(5):495-501.

23. Jover JA, Hernandez-Garcia C, Morado IC, Vargas E, Banares A, Fernandez-Gutierrez B. Combined treatment of giant-cell arteritis with methotrexate and prednisone. a randomized, double-blind, placebocontrolled trial. Ann Intern Med. 2001;134(2):106-114.

24. Mahr AD, Jover JA, Spiera RF, et al. Adjunctive methotrexate for treatment of giant cell arteritis: an individual patient data meta-analysis. Arthritis Rheum. 2007;56(8):2789-2797.

25. Hoffman GS, Cid MC, Rendt-Zagar KE, et al. Infliximab for maintenance of glucocorticosteroid-induced remission of giant cell arteritis: a randomized trial. Ann Intern Med. 2007;146(9):621-630.

26. Martinez-Taboada VM, Rodriguez-Valverde V, Carreno L, et al. A double-blind placebo controlled trial of etanercept in patients with giant cell arteritis and corticosteroid side effects. Ann Rheum Dis. 2008;67(5):625-630.

27. Seror R, Baron G, Hachulla E, et al. Adalimumab for steroid sparing in patients with giant-cell arteritis: results of a multicentre randomised controlled trial. Ann Rheum Dis. 2014;73(12):2074-2081.

28. Langford CA, Cuthbertson D, Ytterberg SR, et al. A randomized, double-blind trial of abatacept (CTLA-4Ig) for the treatment of giant cell arteritis. Arthritis Rheumatol. 2017;69(4):837-845.

29. Villiger PM, Adler S, Kuchen S, et al. Tocilizumab for induction and maintenance of remission in giant cell arteritis: a phase 2, randomised, doubleblind, placebo-controlled trial. Lancet. 2016;387(10031):1921-1927.

30. Stone JH, Tuckwell K, Dimonaco S, et al. Trial of tocilizumab in giantcell arteritis. N Engl J Med. 2017;377(4):317-328.

31. Weyand CM, Hicok KC, Hunder GG, Goronzy JJ. The HLA-DRB1 locus as a genetic component in giant cell arteritis. Mapping of a disease-linked sequence motif to the antigen binding site of the HLADR molecule. J Clin Invest. 1992;90(6):2355-2361.

32. Carmona FD, González-Gay MA, Martín J. Genetic component of giant cell arteritis. Rheumatology. 2014;53(1):6-18.

33. Dababneh A, Gonzalez-Gay MA, Garcia-Porrua C, Hajeer A, Thomson W, Ollier W. Giant cell arteritis and polymyalgia rheumatica can be differentiated by distinct patterns of HLA class II association. J Rheumatol. 1998;25(11):2140-2145.

34. Mackie SL, Taylor JC, Haroon-Rashid L, et al. Association of HLADRB1 amino acid residues with giant cell arteritis: genetic association study, meta-analysis and geo-epidemiological investigation. Arthritis Res Ther. 2015;17(1):195.

35. Carmona FD, Mackie SL, Martin J-E, et al. A large-scale genetic analysis reveals a strong contribution of the HLA class II region to giant cell arteritis susceptibility. Am J Hum Genet. 2015;96(4):565-580.

36. Hutchinson J. Diseases of the arteries. Arch Surg. 1890;1:323-333.
37. Horton BT, Magath TB, Brown GE. Arteritis of the temporal vessels. Arch Intern Med. 1934;53:400-409.

38. Bas-Lando M, Breuer GS, Berkun Y, Mates M, Sonnenblick M, Nesher G. The incidence of giant cell arteritis in Jerusalem over a 25-year period: annual and seasonal fluctuations. Clin Exp Rheumatol. 2007;25(1 suppl 44):S15-7.

39. Gonzalez-Gay MA, Miranda-Filloy JA, Lopez-Diaz MJ, et al. Giant cell arteritis in northwestern Spain: a 25-year epidemiologic study. Medicine (Baltimore). 2007;86(2):61-68.

40. Kisza K, Murchison AP, Dai Y, et al. Giant cell arteritis incidence: analysis by season and year in mid-Atlantic United States. Clin Exp Ophthalmol. 2013;41(6):577-581.

41. Alvarez-Lafuente R, Fernandez-Gutierrez B, Jover JA, et al. Human parvovirus B19, varicella zoster virus, and human herpes virus 6 in temporal artery biopsy specimens of patients with giant cell arteritis: analysis with quantitative real time polymerase chain reaction. Ann Rheum Dis. 2005;64(5):780-782.

42. Russo MG, Waxman J, Abdoh AA, Serebro LH. Correlation between infection and the onset of the giant cell (temporal) arteritis syndrome. A trigger mechanism? Arthritis Rheum. 1995;38(3):374-380.

43. Gilden D, White T, Khmeleva N, Katz BJ, Nagel MA. Blinded search for varicella zoster virus in giant cell arteritis (GCA)-positive and GCA-negative temporal arteries. J Neurol Sci. 2016;364:141-143.

44. Muratore F, Croci S, Tamagnini I, et al. No detection of varicella-zoster virus in temporal arteries of patients with giant cell arteritis. Semin Arthritis Rheum. 2017;47(2):235-240.

45. Weyand CM, Goronzy JJ. Immune mechanisms in medium and largevessel vasculitis. Nat Rev Rheumatol. 2013;9(12):731-740.

46. Watanabe R, Goronzy JJ, Berry G, Liao YJ, Weyand CM. Giant cell arteritis: from pathogenesis to therapeutic management. Curr Treat Options Rheumatol. 2016;2(2):126-137.

47. Dasgupta B, Panayi GS. Interleukin-6 in serum of patients with polymyalgia rheumatica and giant cell arteritis. Br J Rheumatol. 1990;29(6):456-458.

48. Weyand CM, Fulbright JW, Hunder GG, Evans JM, Goronzy JJ. Treatment of giant cell arteritis: interleukin- 6 as a biologic marker of disease activity. Arthritis Rheum. 2000;43(5):1041-1048.

49. Roche NE, Fulbright JW, Wagner AD, Hunder GG, Goronzy JJ, Weyand CM. Correlation of interleukin- 6 production and disease activity in polymyalgia rheumatica and giant cell arteritis. Arthritis Rheum. 1993;36(9):1286-1294.

50. Villiger PM, Cronin MT, Amenomori T, Wachsman W, Lotz M. IL-6 production by human T lymphocytes. Expression in HTLV-1-infected but not in normal T cells. J Immunol. 1991;146(2):550-559.

51. Hirano T, Yasukawa K, Harada H, et al. Complementary DNA for a novel human interleukin (BSF-2) that induces B lymphocytes to produce immunoglobulin. Nature. 1986;324(6092):73-76.

52. Stahl N, Boulton TG, Farruggella T, et al. Association and activation of Jak-Tyk kinases by CNTF-LIF-OSM-IL-6 beta receptor components. Science. 1994;263(5143):92-95.

53. Naka T, Nishimoto N, Kishimoto T. The paradigm of IL-6: from basic science to medicine. Arthritis Res. 2002;4(suppl 3):S233- 42.

54. Hibi M, Murakami M, Saito M, Hirano T, Taga T, Kishimoto T. Molecular cloning and expression of an IL-6 signal transducer, gp130. Cell. 1990;63(6):1149-1157.

55. Fujimoto M, Serada S, Mihara M, et al. Interleukin-6 blockade suppresses autoimmune arthritis in mice by the inhibition of inflammatory Th17 responses. Arthritis Rheum. 2008;58(12):3710-3719.

56. Haruta H, Ohguro N, Fujimoto M, et al. Blockade of interleukin-6 signaling suppresses not only Th17 but also interphotoreceptor retinoid binding protein-specific Th1 by promoting regulatory $\mathrm{T}$ cells in experimental autoimmune uveoretinitis. Investig Ophthalmol Vis Sci. 2011;52(6):3264-3271.

57. Korn T, Mitsdoerffer M, Croxford AL, et al. IL-6 controls Th17 immunity in vivo by inhibiting the conversion of conventional T cells into Foxp3+ regulatory T cells. Proc Natl Acad Sci USA. 2008;105(47):18460-18465. 
58. Nishimoto N, Kishimoto T, Yoshizaki K. Anti-interleukin 6 receptor antibody treatment in rheumatic disease. Ann Rheum Dis. 2000;59(suppl 1):i21-i27.

59. Sheppard M, Laskou F, Stapleton PP, et al. Tocilizumab (Actemra). Hum Vaccin Immunother. 2017;13(9):1972-1988.

60. Nishimoto N. Clinical studies in patients with Castleman's disease, Crohn's disease, and rheumatoid arthritis in Japan. Clin Rev Allergy Immunol. 2005;28(3):221-230.

61. Illei GG, Shirota Y, Yarboro $\mathrm{CH}$, et al. Tocilizumab in systemic lupus erythematosus: data on safety, preliminary efficacy, and impact on circulating plasma cells from an open-label phase I dosage-escalation study. Arthritis Rheum. 2010;62(2):542.

62. Nishimoto N, Nakahara H, Yoshio-Hoshino N, Mima T. Successful treatment of a patient with Takayasu arteritis using a humanized anti-interleukin-6 receptor antibody. Arthritis Rheum. 2008;58(4):1197-1200.

63. Unizony S, Arias-Urdaneta L, Miloslavsky E, et al. Tocilizumab for the treatment of large-vessel vasculitis (giant cell arteritis, Takayasu arteritis) and polymyalgia rheumatica. Arthritis Care Res. 2012;64(11):1720-1729.

64. Lally L, Forbess L, Hatzis C, Spiera R. Brief report: a prospective open-label phase IIa trial of tocilizumab in the treatment of polymyalgia rheumatica. Arthritis Rheumatol. 2016;68(10):2550-2554.

65. Suematsu R, Ohta A, Matsuura E, et al. Therapeutic response of patients with adult Still's disease to biologic agents: multicenter results in Japan. Mod Rheumatol. 2012;22(5):712-719.

66. Singh JA, Beg S, Lopez-Olivo MA. Tocilizumab for rheumatoid arthritis: a Cochrane systematic review. J Rheumatol. 2011;38(7):10-20.

67. Smolen JS, Beaulieu A, Rubbert-Roth A, et al. Effect of interleukin-6 receptor inhibition with tocilizumab in patients with rheumatoid arthritis (OPTION study): a double-blind, placebo-controlled, randomised trial Lancet. 2008;371(9617):987-997.

68. Genovese MC, McKay JD, Nasonov EL, et al. Interleukin-6 receptor inhibition with tocilizumab reduces disease activity in rheumatoid arthritis with inadequate response to disease-modifying antirheumatic drugs: The tocilizumab in combination with traditional disease-modifying antirheumatic drug the. Arthritis Rheum. 2008;58(10):2968-2980.

69. Kremer JM, Blanco R, Brzosko M, et al. Tocilizumab inhibits structural joint damage in rheumatoid arthritis patients. Arthritis Rheum. 2011;63:609-621.

70. Jones G, Sebba A, Gu J, et al. Comparison of tocilizumab monotherapy versus methotrexate monotherapy in patients: the AMBITION study. Ann Rheum Dis. 2010;69:88-96.

71. Campbell L, Chen C, Bhagat SS, Parker RA, Östör AJK. Risk of adverse events including serious infections in rheumatoid arthritis patients treated with tocilizumab: a systematic literature review and metaanalysis of randomized controlled trials. Rheumatology. 2011;50(3): $552-562$.

72. Navarro-Millán I, Singh JA, Curtis JR. Systematic review of tocilizumab for rheumatoid arthritis: a new biologic agent targeting the interleukin-6 receptor. Clin Ther. 2012;34(4):788-802.e3.

73. Emery P, Keystone E, Tony HP, et al. IL-6 receptor inhibition with tocilizumab improves treatment outcomes in patients with rheumatoid arthritis refractory to anti-tumour necrosis factor biologicals: results from a 24-week multicentre randomised placebo-controlled trial. Ann Rheum Dis. 2008;67(11):1516-1523.
74. Kremer JM. Tocilizumab inhibits structural joint damage in rheumatoid arthritis patients with inadequate responses to methotrexate: results from the double-blind treatment phase of a randomized placebo-controlled trial of tocilizumab safety and prevention of structure. Arthritis Rheum. 2011;63:609-621.

75. Burmester GR, Rubbert-Roth A, Cantagrel A, et al. Efficacy and safety of subcutaneous tocilizumab versus intravenous tocilizumab in combination with traditional DMARDs in patients with RA at week 97 (SUMMACTA). Ann Rheum Dis. 2016;75(1):68-74.

76. Seitz M, Reichenbach S, Bonel HM, Adler S, Wermelinger F, Villiger PM. Rapid induction of remission in large vessel vasculitis by IL-6 blockade. A case series. Swiss Med Wkly. 2011;141:w13156.

77. Loricera J, Blanco R, Hernandez JL, et al. Tocilizumab in giant cell arteritis: multicenter open-label study of 22 patients. Semin Arthritis Rheum. 2015;44(6):717-723.

78. Regent A, Redeker S, Deroux A, et al. Tocilizumab in giant cell arteritis: a multicenter retrospective study of 34 patients. J Rheumatol. 2016;43(8):1547-1552.

79. Maini RN, Taylor PC, Szechinski J, et al. Double-blind randomized controlled clinical trial of the interleukin-6 receptor antagonist, tocilizumab, in European patients with rheumatoid arthritis who had an incomplete response to methotrexate. Arthritis Rheum. 2006;54(9):2817-2829.

80. Yazici Y, Curtis JR, Ince A et al. Efficacy of tocilizumab in patients with moderate to severe active rheumatoid arthritis and a previous inadequate response to disease-modifying antirheumatic drugs: the ROSE study. Ann Rheum Dis. 2012;71(2):198-205.

81. Weinblatt ME, Kremer J, Cush J, et al. Tocilizumab as monotherapy or in combination with nonbiologic disease-modifying antirheumatic drugs: Twenty-four-week results of an open-label, clinical practice study. Arthritis Care Res. 2013;65:362-371.

82. Dougados M, Kissel K, Conaghan PG, et al. Clinical, radiographic and immunogenic effects after 1 year of tocilizumab-based treatment strategies in rheumatoid arthritis: the ACT-RAY study. Ann Rheum Dis. 2014;73:803-809.

83. Burmester GR, Rigby WF, van Vollenhoven RF, et al. Tocilizumab in early progressive rheumatoid arthritis: FUNCTION, a randomised controlled trial. Ann Rheum Dis. 2016;75:1081-1091.

84. Kaneko Y, Atsumi T, Tanaka Y, et al. Comparison of adding tocilizumab to methotrexate with switching to tocilizumab in patients with rheumatoid arthritis with inadequate response to methotrexate: 52-week results from a prospective, randomised, controlled study (SURPRISE study). Ann Rheum Dis. 2016;75:1917-1923.

85. Tuckwell K, Collinson N, Klearman M, Dimonaco S, Stone JH. Baseline data on patients enrolled in a randomized, double-blind trial of tocilizumab in giant cell arteritis. Arthritis Rheumatol. 2015;67(suppl 10):59-60.

86. Schmidt J, Smail A, Roche B, et al. Incidence of severe infections and infection-related mortality during the course of giant cell arteritis: a multicenter, prospective, double-cohort study. Arthritis Rheumatol. 2016;68(6):1477-1482.

87. Adler S, Reichenbach S, Kuchen S, et al. Termination of TocilizumabTreatment in Giant Cell Arteritis: Follow-up of Patients after the RCT (ClinicalTrials.gov registration number: NCT01450137) [abstract]. Arthritis Rheumatol. 2016;68(suppl 10).
Eye and Brain

\section{Publish your work in this journal}

Eye and Brain is an international, peer-reviewed, open access journal focusing on clinical and experimental research in the field of neuroophthalmology. All aspects of patient care are addressed within the journal as well as basic research. Papers covering original research, basic science, clinical and epidemiological studies, reviews and evaluations,

Submit your manuscript here: https://www.dovepress.com/eye-and-brain-journal guidelines, expert opinion and commentary, case reports and extended reports are welcome. The manuscript management system is completely online and includes a very quick and fair peer-review system, which is all easy to use. Visit http://www.dovepress.com/testimonials.php to read real quotes from published authors. 